\title{
Roman Catholic Perceptions of British and American Protestant Missionaries (1807-1920)
}

\author{
Jean-Paul WIEST*
}

\section{Introduction}

Some time ago a colleague asked me about what I thought and read on Catholic and Protestant missionaries' perceptions of each other prior to World War I. My answer was rather blunt: "Catholic missionaries did not have much to say that was good about Protestant missionaries and vice-versa-quite paradoxical for people preaching to love one another!"

My friend's question prompted me to pay more attention to how both sides viewed and dealt with each other, and as I gathered material on the subject, my assessment of their relationship became more nuanced. In this essay, I do not pretend to submit an exhaustive assessment of the entire spectrum of what were then called the mission fields. I have limited myself to the one field I know fairly well, the China mission, which provides, in my judgment, a vivid and accurate representation of what happened in other mission countries when Protestant and Catholic missionaries came face to face. The material I introduce is arranged topically and put into its proper context. As much as possible, I avoid paraphrasing the subjects of this inquiry. Rather, I let them speak for themselves so that we may savor, so to speak, the flavor of their prose.

I begin with an overview of how Protestants viewed Catholics. Far from being a departure from the chosen topic, this will serve as the frame of reference for the rest of the paper when we consider Catholic perceptions and critiques of Protestant missions.

\section{Protestant Views of Roman Catholic Missionaries}

Scholars looking into the topic of Catholic-Protestant relations during the period in question are unanimous in pointing out that negative opinions and attitudes by far outweighed positive ones. Kenneth Scott Latourette writes,

\footnotetext{
* Research Director, The Beijing Center for Chinese Studies.
} 
In all these pioneering efforts, Roman Catholic Missions were practically ignored. To the Protestant it was as if the Catholics had never come to China. Protestants nearly always thought of themselves as the sole representatives of the Gospel and spoke of "opening" cities and provinces to the Christian message even when Catholics had been there before them. This was natural. By the average Protestant of the time Rome was thought of as anti-Christian. At best, Roman Catholicism was regarded as a corrupt form of Christianity from which the Reformers had, at great cost and suffering, escaped to restore the Gospel in its purity. ${ }^{1}$

Ralph Covell, in his book Confucius, the Buddha, and Christ, comes out with a similar assessment and provides typical arguments used by Protestant missionaries:

When Protestants reached China..., "Jesuit" was a dirty epithet that expressed the Protestant revulsion for almost every aspect of Catholic missionary strategy, such as "sneaking into China" in Chinese garb, working with the officials and gentry rather than with the common people, insisting on the authority of the pope, and using "non spiritual" means such as "the calculation of eclipses, or the arrangement of the calendar."2

Bob White, in Unfinished Encounter, shows, however, that some missionaries, like Charles Gutzlaff and Hudson Taylor, were much more balanced in their assessment of their Catholic counterparts:

Charles Gutzlaff's attitude towards the Jesuits was in part admiration, in part criticism. Popery and Romanism were anathema but he admired the courage, dedication and intelligence of the Jesuits. Gutzlaff's attitude was perhaps more generous than many, although Hudson Taylor was to adopt a similar standpoint, expressing his appreciation of the courage of Catholic priests in traveling into the interior at the risk of their lives: "Entering by stealth, living in concealment, ... ever and anon meeting with imprisonment, torture, and death itself, they have presented a remarkable instance of fidelity by their calling."3

1 Kenneth Scott Latourette, A History of Christian Missions in China (New York: Macmillan, 1929), p.361.

2 Ralph R. Covell, Confucius, the Buddha, and Christ: A History of the Gospel in Chinese (Maryknoll, N.Y.: Orbis Books, 1986), p. 69.

3 Bob Whyte, Unfinished Encounter, China and Christianity (Glasgow: Collins, 1988), p.110. See also Covell, Confucius, the Buddha, and Christ. P. 69. 
The following remark from an English Presbyterian at Shantou in 1870 is typical of what other Protestant missionaries in China thought: "Alas! China knows more of Popery than of true Christianity, and if we ourselves dread the political influence of a religion which has earthly head in an alien country, we can sympathize with the Chinese in their fear to some extent." 4

Yet practicality and circumstances led many Protestant missionaries to adapt to the Catholic reality in China. As is well known, Robert Morrison, upon arriving in Canton in 1807, enlisted the assistance of Chinese Catholics to learn the language and used Father Jean Basset's Chinese translation of the New Testament to assist him in his own translation work. ${ }^{5}$ And he did this in the face of strong opposition by the Chinese clergy from Macao who administered the small Catholic community in and around the city. A few years later in that same city, Dr. Samuel Wells Williams was willing to recognize that "there may have been true converts among the adherents to Romanism." 6 The American Presbyterian Rev. B. C. Henry kept "trusting that in the flocks gathered by these self-denying priests there might be many who, through the imperfect light brought them, have been led to a true knowledge of the Lord of all and Jesus, his son."

Meanwhile, on the home front, Protestant publications showed no significant relenting of their attacks against Catholics. The March 14, 1907, issue of a Cincinnati publication called God's Revivalist and Bible Advocate, for instance, asserted,

Catholicism is much worse in heathen countries than in America. Shall we, because of our selfishness, see China's little ones brought up Catholics, when we, by putting forth a little effort, can rescue them and train them to God? It is sad, but true, that we have to stand by and see the harvest go to waste, see the grain spoil for lack of reapers. ${ }^{8}$

Finally, for another interesting angle on the Protestants' views of Catholics in China, one should carefully read the book of Jesuit Father Bertram Wolferstan published in 1909 under the title The Catholic Church in China. Chapter 3, entitled "Catholic Missions from Another Point of View," shows how Catholics carefully culled through the Protestant literature and how they

4 Quoted in Whyte, Unfinished Encounter: China and Christianity. p. 110.

5 François Barriquand, "First Comprehensive Translation of the New Testament in Chinese: Fr. Jean Basset (1662-1707) and the Scholar John Xu"," Verbum SVD 49, 1 (2008): 91-119.

6 S. Wells Williams, The Middle Kingdom, revised edition (New York: C. Scribner's Sons, 1883), vol.2, p. 317.

7 B. C. Henry, The Cross and the Dragon (London: S. W. Partridge, 1884), pp.425-426.

8 Reprinted in The Field Afar, May 1907, p. 12. 
understood it. 9

\section{Catholic Views of Protestant Missionaries and Their Work}

During the period under study, the Roman Catholic clergy's view of Protestant missionaries and their work did not remain static, but rather went through several overlapping phases, each phase layering on top of the previous one new perceptions and descriptions of the "competitors." At first the newcomers were made fun of. Soon, however, they were seen as troublemakers. Then they were described as people who confuse the Chinese and make the task of conversion more difficult. And finally, they were perceived as a threat that needed to be counteracted by reasserting the superiority of Catholic methods. In addition, of course, Protestant missionaries all along were mostly portrayed as antagonistic and uncompromising zealots who tried to steal Chinese converts away from Catholic missionaries.

\subsection{First Phase}

In the first phase Catholic missionaries treated their protestant counterparts with scorn and ridicule. When Protestant missionaries made their first appearances along the China coast, the Catholic clergy, for the most part, did not take them seriously. Catholic clerics compared them to "commercial travelers armed with prospectus," and described their methods as being nothing more than "tossing Bibles from shipside upon the beach." 10 There was therefore nothing to worry about because Protestants would fail and soon go back on the same boats that brought them over. So Catholic missionary writings about the early days of the Protestant presence mostly made fun of the Protestants and their methods:

Two Protestant ministers have arrived in Shanghai and their main activity is to distribute books - more than 30,000 to this day. And we, their good confreres, we burn them as we find them. Everybody knows that these ministers of the so-called reform distribute bibles, but what many may not know is that they also distribute medals. Unbelievable, would you say? I would not have believed it myself if I had not seen it with my own eyes. But what do we find represented on these medals? The picture of Our Lord, or that of his Holy Mother, or that of some saint? No, you guessed wrong! What I saw on one of these supposedly reformed medallions was the head of an unidentifiable animal. Some Chinese who looked at the medals claimed that the engraving represents

9 Bertram Wolferstan, S.J., The Catholic Church in China (St. Louis: B. Herder, 1909).

10 Comment made in the 1830s by a French Vincentian; quoted in Peter Fay, Opium War (New York: Norton, 1976), p. 242. 
the devil because on each side of the head there are protrusions resembling the horns of a ram. So, these gentlemen who dare to accuse the Catholic Church of idolatry because it asks its followers to revere images of Our Lord, the Mother of God and the saints, believe that they have accomplished an opportune reform by substituting a bizarre horned beast to some of our most venerable and sacred objects. ${ }^{11}$

These attempts at belittling the newcomers were in great part an artifice used by Catholic missionaries to avoid alarming the readership back home. In fact, the Catholic clergy in China was quite concerned by the progress of Protestantism and began to display an overtly hostile attitude toward its ministers. ${ }^{12}$ In Catholic writings such as the preceding quote, one can detect a faint but real undercurrent of uneasiness that at times surfaces in brief and biting bursts of spite. That same missionary, for instance, had barely finished making fun of the two Protestants in Shanghai when he lashed out at them for having "debauched" one of his deacons and then declared that the arrival of Protestantism in China was a "scourge comparable to the introduction of opium." 13 Accusations against Protestant missionaries' "deceitful tactics" to entice Chinese Catholics to become Protestants abound during the entire period.

\subsection{Second Phase}

In the second phase Catholic missionaries viewed Protestant missionaries as troublemakers. From the late 1840s on, as Catholic missionaries began to realize that the presence of Protestant missionaries was not just a passing phenomenon, their tactic tended to shift towards describing them as agents of disturbance. Typical is an 1865 letter of Bishop Michele Navarro, vicarapostolic of Hunan, describing the activities of Protestants in the city of Hengyang in these terms:

At the beginning of April, we suffered painful trials. Three American Protestant ministers arrived at the time of the general examinations when the number of students had risen to at least ten thousand. The arrival of strangers excited general emotion, produced by the unheard of sight of

11 Lettres des Nouvelles Missions de la Chine, vol. 1, letter of Father Estève, June 1, 1845, pp.229-230.

12 See, for instance, Father Renou's report of June 22, 1849, urging the Paris Foreign Missions Society to reestablish itself in the city of Canton where "Protestant missionaries are already preaching, distributing bibles and opening places of worship" (Archives of the Missions Etrangères de Paris, vol.550).

13 Lettres des Nouvelles Missions de la Chine, vol.1, p. 229. 
Europeans who were not clothed in Chinese fashion. The latter, becoming frightened, took refuge in the prefect's yamen and then, fearing that this asylum would not be sufficiently safe, returned to their ship. The students threw themselves into boats, crossed the river, and entered the ship. On the following morning, the local newspapers contained the most horrible accusations, and appealed to the popular passions, exciting the people to kill all the Europeans, and to destroy, as they already did before [in 1858 and 1862], our church and our dwelling. 14

\subsection{Third Phase}

In the third phase Catholic missionaries thought that Protestant missionaries confused Chinese people. As we approach the end of the nineteenth century, it becomes almost impossible to find Roman Catholics saying or writing anything positive about Protestants. Latourette perfectly summarized the Catholic literature of the period when he wrote that Protestants were depicted as "dangerous heretics who hindered the work of Christ and were introducing to China the multitudinous sects of Europe and America." 15 What Catholic missionaries seem to stress most is the confusion that Protestantism was causing among the Chinese. Father Bertram Wolferstan cunningly accuses them of leading China from "Confucius to confusion." 16 To prove the point, the Catholic literature even resorts to quoting non-Catholic sources, such as a Chinese author writing that his people "can make neither head or tail of the peculiar intestine dissensions which render these sects asunder," or a British lord musing about "the complete bewilderment of the native understanding, ill able to cope with the subtleties of theological logomachies." 17 Some Catholic missionaries were so troubled by the confusion that this situation caused to "the naturally skeptical [Chinese] mind" that they begin "to doubt if China will ever be Christianized." 18

\subsection{Fourth Phase}

During the first fifteen years of the twentieth century, the writings of the Catholic missionaries regarding the activities of their Protestant counterparts

14 Quoted in Columba Cary-Elwes, China and the Cross: A Survey of Missionary History (New York: P. J. Kenedy and Sons, 1957), p. 216.

15 Latourette, A History of Christian Missions in China, pp.361-362.

16 Wolferstan, The Catholic Church in China, p. 13.

17 Wolferstan, The Catholic Church in China, pp. 18-20, quoting Wen Ching, The Chinese Crisis from Within (1901), and George N. Curzon, Problems of the Far East (New York: Longmans, Green and Co., 1896).

18 Quoted in Wolferstan, The Catholic Church in China, p.22. 
and the future of Christianity in China seem to focus on two closely linked themes.

3.4.1 The First Recurring Theme The first recurring theme was that the success of Protestant missionaries was a threat to Catholic missions. One still finds, of course, the tune of "confusion" being played out in Catholic missionary writings. For instance, Jesuit Father Martin Kennelly described the evangelistic work carried out by YMCAs in these words:

It consists mainly in Bible studies, each participant being left to find out what religion is the true one. Obviously no one finds out and the greater number is puzzled to choose among Protestant denominations, so varying and contradictory are the sects in doctrine, church government, sacraments and worship. ${ }^{19}$

A more prevalent theme repeated over and over that if Catholics in Europe and America did not wake up and come to the rescue, Protestantism would displace Catholicism in China. The success of the Protestants was attributed to several factors. First among these was the vitality of Protestantism, especially in North America:

The vital spot in Protestantism today is its zeal for domestic and foreign missions. The missionary box is in almost every house. Among Protestants whose blessings are so much fewer than ours, whose churches stand for so little in comparison with the Catholic church, there is, nevertheless, a splendid missionary enthusiasm almost incomparable and but for which Protestantism would have perished. ${ }^{20}$

As a result of this vitality, Catholic missionaries witnessed the en masse arrival of highly motivated and well-funded Protestant apostles:

We admire in our Protestant fellow-countrymen the energy and the spirit of generosity, which enable them to send out propagandists in everincreasing numbers, and we believe that among those who go forth to "conquer souls" some are sincere in their purpose. Yet this spread of heresy renders still more difficult the self-sacrificing labors of Catholic missionaries. These latter find it hard in their poverty to win the attention of natives whose material necessities are often readily met at a wellsustained Protestant mission. ${ }^{21}$

19 The Field Afar, August 1914, p.8.

20 The Field Afar, July 1907, p. 12.

21 The Field Afar, January 1907, p. 2. 
But the success of Protestant missionaries was also attributed to less lofty practices. Already mentioned was the practice of stealing Christians from Catholic congregations. In addition, Catholic missionaries described many of their Protestant counterparts as "most bigoted" persons who "do not even admit that Catholics are Christians" and who like to badmouth them:

Frequently, the stock calumnies, which have been served up in this country [the United States] until our own fair-minded non-Catholics were nauseated, are still used on the foreign mission field, not by all, but, we regret to say, by too many American Protestant missionaries. Thus our own countrymen are preventing the labors of Catholic missionaries. ${ }^{22}$

In summary, by 1907 , some one hundred years after the arrival of Robert Morrison, Catholic missionaries had come to realize that the Protestant presence in China, far from being a passing phenomenon, was becoming a more and more encompassing reality that threatened their work: "Protestant missionary activity," wrote the editor of The Field Afar, "is an obstacle and in some places a serious obstacle to Catholic advance." 23 In 1913, a published letter of Bishop Augustin Henninghaus, vicar apostolic of South Shandong, bluntly presented the situation and sounded a wake-up call for Catholic America:

Protestant America is unquestionably a strong power in our midst. Not long ago an American, Dr. Mott, gave religious lectures in the largest cities of China, which attracted unusual attention. The Young Men's Christian Association is very active and has won great influence. The modern school system and the press are to no small extent in the hands of Protestant America. It is time to say, "Catholic America to the front!" 24

3.4.2 The Second Recurring Theme The second recurring theme was that therefore it was imperative for Catholic America to do its part to counter the Protestant success in China. The preceding letter is one of many that, since the turn of the century, challenged Catholics of the United States to engage in a large-scale missionary effort abroad and also to publicize the work of English-speaking Catholic missionaries. ${ }^{25}$ From its inception in January 1907,

22 The Field Afar, October 1907, p. 4; August-September 1911, p. 6. See also the December 1908 issue, p. 3.

23 The Field Afar, December 1908, p. 3.

24 The Field Afar, October 1913, p. 2.

25 See, for instance, The Illustrated Catholic Missions, vol. 12 (November 1897), p. 112. 
The Field Afar, which would soon become the official publication of the Catholic Foreign Mission Society of America, better known as Maryknoll, did much to promote this dual cause. In his first article, commenting on the "great army" of missionaries that the American Protestants maintain in "foreign fields," the editor wrote,

Would that we Catholics of the US could point to a similar force of men and women, self-exiled for the spread of the true faith! .. . The Christianity of America has been too long represented in the foreign missions, solely by Protestantism, and the time has surely come when we Catholics of the US should enter upon our task among people who are ours by the inheritance of Jesus Christ. ${ }^{26}$

For the Catholic Church in America it was a matter of honor "to rid the Chinese of the deep-rooted idea that American and Protestant are one and the same." 27 So American Catholics were constantly challenged "to counteract" the influence of American Protestants "by giving better support to the men and women who represent [them] in the foreign field." 28

\subsection{The Overarching Theme for the Entire Period}

The overarching theme for the entire period was that in the long run, Catholic missionaries' methods of evangelization were the best. Yet as years went by, Catholic missionaries' appraisals of their Protestant counterparts became more nuanced. One notices many instances showing real appreciation and respect. For instance, the same Father Kennelly who accuses Protestants of being "bigoted" also says that he finds them, "as a rule, obliging, and some of them have rendered me great services for which I am grateful." 29

The Protestants' success was in great part due to a variety of approaches facilitated by an abundance of financial means. Well aware of the situation, Catholic missionaries often wrote about it in missionary journals, hoping to stimulate the generosity of Catholics back home, especially those in the United States:

Another good example is Lettre ouverte aux Catholiques d'Amérique (Open Letter to Catholics in America), written on January 15, 1914, by Francis Gervaix, a Paris Foreign Missions missionary in Guangzhou, in which he begged American missionaries to hurry to China to counteract the errors spread by their fellow American Protestant missionaries (see Maryknoll Archives, Canton Archives box, letters and documents 1910-1920 folder).

26 The Field Afar, January 1907, p. 2

27 The Field Afar, September 1915, p. 134

28 The Field Afar, October 1907, p. 4. See also, for instance, the August-September 1911 issue, p. 7.

29 The Field Afar, August-September 1911, p.6. 
The wealth of Protestant missions is appealing. Stocked dispensaries and fully equipped hospitals for the afflicted; well-supplied larders to feed the hungry; vast quantities of clothing; first-class organizations of schools, colleges, and even universities - these, it cannot be denied, are powerful attractions. ${ }^{30}$

Yet as a counterbalance, the Catholic missionary press never failed to describe some of the Protestant methods and behaviors as totally inept for China and thus continued to make fun of their efforts:

During the year 1912, the British Foreign Bible Society distributed in China 1,868,000 copies of the Scriptures. This has helped little to advance the conversion of the people, for the Chinese are illiterate and cannot master enough of the written characters to enable them to understand the text. Besides, there are no notes and as the book does not explain itself, all is practically a dead loss. It is said that many petty shopkeepers use the paper to wrap up objects for sale, while shoemakers find it an excellent and cheap material for soles. . . . General Bromwell Booth, head of the Salvation Army, contemplates sending a strong force to China. With the semi-military organization of the Salvationists, there is danger that the people will take this step as an invasion and resist it. The best missionary work in China, as elsewhere, has always been done with the least fuss. The Salvation Army will have to change its character considerably when it comes to the East. ${ }^{31}$

So the emphasis remained on affirming the superiority of Catholic methods and pointing to weaknesses in the Protestant approach. But to achieve some sense of impartiality, the Catholic press liked to borrow directly from the Protestant literature and then add to it its own spin. For instance, in February 1913 The Field Afar provided the following excerpt from a report made during a recent mass meeting of the International Bible Students Association in the New York Hippodrome:

Christianizing endeavors (in the Orient) seem generally to have ceased. Present missionary activity is almost exclusively along the lines of secular education. There are evidences of positive teachings in the past, but very little religious teaching is being done now, because the people would resent it and keep their children from the schools. Aside from the educational advantages, the inducements offered by the missionaries are chiefly social and medical.

30 The Field Afar, December 1908, p.3; see also the October 1907 issue, p. 4.

31 The Field Afar, April 1914, p. 6. 
The Field Afar's editor then commented,

We believe these sentences speak for themselves of the missionary work, which aims to civilize rather than to Christianize, which seeks to dispel the darkness of Oriental paganism by the "culture" of Western education and unbelief. 32

Another stratagem used all along in the Catholic press and literature was to have non-Christians or, even better, the Protestants themselves declare that the Catholics were doing a superior job:

Some of the fair-minded Protestants admit that the Catholic missionary's work among the heathen is more effective and more lasting than their own. They ascribe this influence especially to the life of celibacy, which the Catholic priest leads and which enables him to become "all to all." The assertion was once made to the writer that if Catholic missionaries were supplied with the means provided the Protestants in the same districts, the latter would soon find it necessary to move. ${ }^{33}$

\section{Conclusion}

Looking at the history of the expansion of Christianity from the particular angle of the writings of missionaries about each other, I could not hold back my personal feelings about the situation, despite my training as a professional historian to offer only a detached historical analysis. I felt both saddened and cheered by what I read and found.

I was saddened by the naivety of the Western missionaries and their sense of self-righteousness. I was equally saddened by their failure to realize that their divisions and badmouthing were contrary to the deepest message of Christianity. I was, however, cheered by the practical deeds of cooperation and by the open-minded attitude of quite a few real harbingers of the ecumenical and interreligious dialogue more prevalent in our days.

In this regard, my cutoff date of 1920 does not seem at first to have much significance, because for several decades thereafter, one cannot detect a drastic change of attitudes. Most Western Protestant and Catholic missionaries still bitterly opposed one another and passed that same attitude of mistrust to their followers. But on second thought, the period from 1915 to 1920 is after all very significant because it was rich in events such as the Great War in Europe, the rise of Chinese nationalism, and the birth of Chinese communism-events that in the long run would bring about profound changes in

32 The Field Afar, February 1913, p. 3.

33 The Field Afar, December 1908, p. 3. 
Western churches' understanding of themselves and affect their relationship with one another as well as with the incipient Chinese Church. The same should be said of the influence of modernism in theology and in the social and political attitudes among missionaries, and of the efforts of the Vatican to regain direct control of the Catholic missionary effort.

During these five years, for instance, the ranks of French missionaries in the Catholic Church in China became severely depleted by the war. American Catholic missionaries arrived to pick up the slack and thus imparted their own mark on the missionary enterprise. On another front, missionaries like Father Vincent Lebbe and Father Anthony Cotta received the support of Rome with the apostolic letter Maximum Illud of November 1919 condemning imperialistic attitudes among missionaries and advocating the process of devolution in the church. These events were just the beginning of a series of events that over the next decades profoundly transformed the attitude of Catholics toward Protestants. In the same manner, one can point to persons and events that in the long run affected the attitudes of Protestants in China toward Catholics. Interesting changes were definitively in the making. 